\title{
Satisfaction of the international students with the content of master's programs in the field of the management at metropolitan university
}

\author{
Olga Fedotova ${ }^{1 *}$,Elena Platonova ${ }^{2}$, Galina Sorokina ${ }^{2}$, and Bu Tong ${ }^{3}$ \\ ${ }^{1}$ Don State Technical University, Faculty "Psychology, Pedagogy and Defectology", 344000, Rostov \\ on Don, Russian Federation \\ ${ }^{2}$ Moscow Pedagogical State University, Institute of Social Studies and Humanities, 119571, Moscow, \\ Russian Federation \\ ${ }^{3}$ Jiangsu Normal University, 221009, Xuzhou, China
}

\begin{abstract}
That paper is motivated by the fact that the development of export potential of higher education is one of the most significant trends in the modern world educational space. The main form of export higher education in Russia is the training of the international students at local universities. In recent years, there has been an increase in the number of foreign citizens studying at Russian universities. However, in order to attract young people from foreign countries, it is important to identify the level of satisfaction of university students with the content of educational programmes, primarily at the master's programs. The study shows the need to strengthen the practical orientation of programs and focus on the individual needs of certain groups of international students, taking into account their future careers and socio-cultural practices in the country in which university graduates are going to work in the position of manager.
\end{abstract}

\section{Introduction}

The most important direction in the strategy of the Russian state in the field of education is the export of educational services, which is the most stable trend in the global educational space. The national Federal project "Education", adopted in December 2018, sets the ambitious goal of increasing by the end of the project (2014) at least two times the number of foreign citizens studying in Russian universities and scientific organizations.

This task is achievable within the scheduled timeframe. Currently, there is a positive upward trend in the number of foreign students enrolment in programs of higher education. From the 2005/2006 academic year to the 2018/2019 academic year, the number of foreign students in Russian universities increased from 78.1 thousand people up to 247.7 thousand people, or in 3.1 times.

Attracting foreign students to study at Russian universities became possible after Russia joined the Bologna process and moved to a new structure of higher education. The introduction of the European system of Bachelor's and Master 's degrees training opened

\footnotetext{
*Corresponding author: fod1953@yandex.ru
} 
the way for Russian education to enter the world educational space [1]. Graduates of Russian universities who obtained Bachelor 's and Master's degrees have become soughtafter and competitive specialists in world and national labour markets.

The historically high level of education formed in Soviet times attracts foreign students especially from CIS countries. According to statistics, about $75 \%$ of foreign students came from CIS countries. Among the member countries of the Shanghai Cooperation Organization, the most active consumers of educational services are citizens of China.

At the same time in strong conditions of the competition in the global educational space the Russian government provides the comprehensive support to the local universities through the implementation of the priority project "Export of Education" with the more than 107.4 billion rubles. That project provides a set of activities to develop all forms of export education and reduce administrative barriers for foreign citizens wishing to obtain Russian higher education diplomas.

The main tool for attracting young people from foreign countries to study at Russian universities should be not only the moderate price of educational programs for undergraduate, graduate and postgraduate studies in comparison with European and American universities [2]. The competitive advantage of Russian universities is the availability of highly qualified university teachers and the quality of the educational services provided to international students [3].

Russian governmental bodies, represented by the Ministry of Science and Higher Education and the Federal Accreditation Service (Rosaccredation), pay the great attention to the control of the quality of educational services provided by universities. The system of monitoring educational activities and accreditation of universities is aimed at compliance by universities with the requirements of state standards and formation of competences provided by Federal State Educational Standards (FSES) for certain professional fields of training of specialists [4].

As a result of monitoring, only formal compliance with the requirements of FSES can be revealed by authorities. Universities are interested in an informal identification of the level of international students' satisfaction with the quality of education and, above all, with the level of satisfaction with the content of master's programs.

One of the ways to identify the satisfaction with the content of master's programs is a questionnaire and a survey of the foreign students at the end of the school year so that in the process of the annual review of educational programs to take into account the comments and wishes of the foreign students

\section{The methodology of the study, data sources and data availability}

Research methods included statistic and graphic methods [5], interpretation [6], questioning [7], survey [8,9], generalization, observation.

During satisfaction determination of the content of master's programs in the field of the management 24 Chinese graduates took part in the questionnaire and survey, or $100 \%$ of foreign students who graduated from the master's program in 2019. Among the participants in the study, 10 graduates mastered the master's program "Financial Management", and 14 students mastered the master's program "International Business". The satisfaction result was evaluated by each questionnaire participant on a point system starting from 1 (minimum satisfaction) to 10 (maximum satisfaction). The Department of Economic Theory and Management of the Moscow Pedagogical State University (MPSU) in May 2019 before the graduation tests conducted the research. 


\section{Results and discussion}

After the questionnaires were processed, surveys of graduates were conducted to clarify their opinion to the content of a number of modules of disciplines presented in the curricula prepared in accordance with FSES for the Educational Program: 38.04.02 Management (qualification (degree) "Master").

The content of the master's programs in the frame of the Educational Program: 38.04.02 Management (qualification (degree) "Master") is reflected in the curriculum, which is designed for a 2-year full-time training course. The Master's degree program is 120 credit units (under the Bologna system) and one credit unit is 36 academic hours. The curriculum should meet the basic principles of the FSES according to which it should consist of the following blocks: Block 1 "Disciplines (modules)"; Block 2 "Practices, including research work (R\&D)"; Block 3 "State final test". The ratio based on credit units between these blocks in the curriculum of master's programs 38.04.02 Management issued in 2017 is shown in Fig 1.

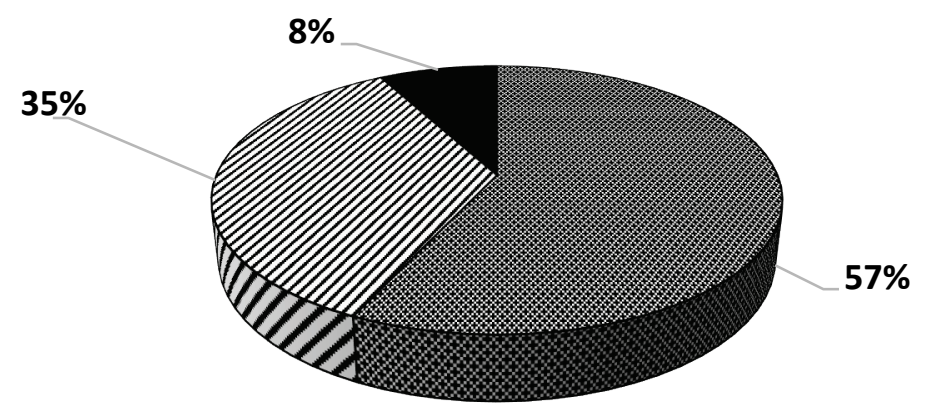

\section{Block 1 "Disciplines (modules)" \\ 口Block 2 "Practices, including research work (R\&D)" \\ Block 3 " State final test".}

Fig. 1. Ratio between three blocks in the curriculum of master's programs 38.04 .02 Management issued in 2017 in MPSU

The main object of the study of satisfaction of the international students with the content of master's programs «Financial Management" and "International Business" was the content of Block 2 (57\%). That block includes the disciplines (modules) related to the basic part of the programs and disciplines (modules) related to its variable part, containing mandatory disciplines and disciplines that a student can choose based on their professional interests (disciplines of the choice).

Fig. 2 shows the correlation based on credit units in the curriculum of the two master programs of the modules making up Block 2. 


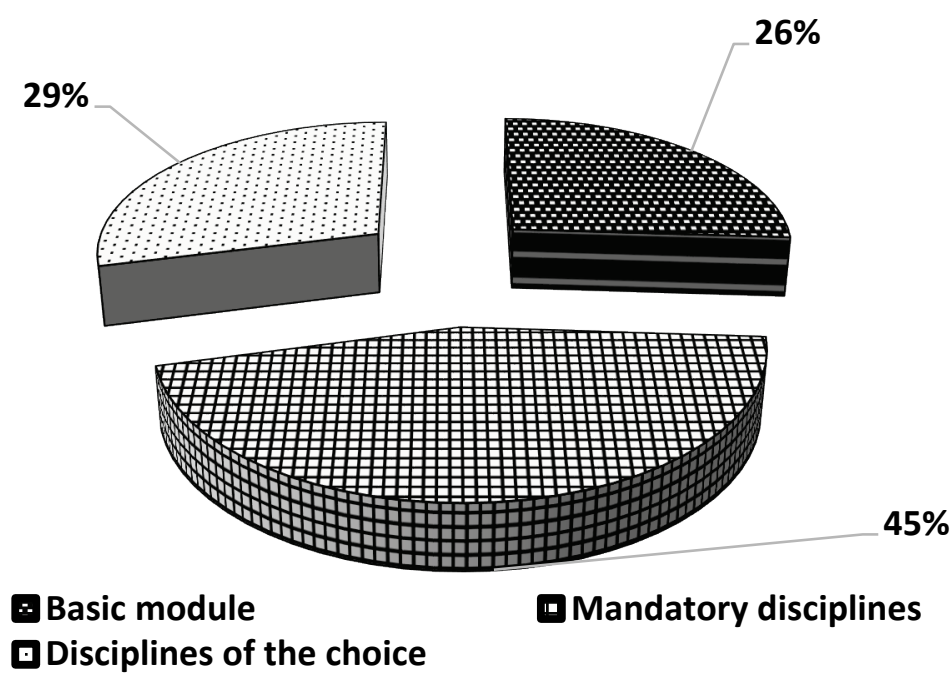

Fig. 2. The ratio between the modules in Block 2 in the curriculum of master's programs (Financial Management and International Business)

As a result of the questioning of the graduates of the master's programs, different assessments of the role of the components of Block 2 in the setting up of their professional competences were established by Chinese students and different levels of satisfaction with the disciplines that make up Block 2. Thus, graduates of the master's program "Financial Management" were quite satisfied with the set of disciplines included in the basic module of the curriculum (average score - 8). Graduates of the master's program "International business" rated their satisfaction with the basic module as low (average score - 5). Graduates have expressed a desire not only to learn the Russian language but also to learn how to read professional texts on the foreign economic activity in the field of RussianChinese business relations taking into account the current legislation of the Russian Federation and China.

The central module in Block 2 is the module of mandatory disciplines. The level of satisfaction of that part of Block 2 of the program of "Finance management" is shown below (Fig.3). Average rating of content satisfaction of this group of disciplines is 7.4 points. The decrease in satisfaction with mandatory disciplines is explained by a number of reasons, among which the main reason is identified by foreign graduates with weak coverage in the content of mandatory disciplines of the peculiarities of financial markets of South-East Asia, China, as well as financial relations in Russian-Chinese cooperation.

The average satisfaction score of Chinese graduates of the International Business program is 7.1 (Fig.4). Graduates have repeated the program during the survey gave consistent assessments. In general, the explanations of their satisfaction level coincide. As well as students of the Financial Management program, graduates of this program noted the need to improve the content of mandatory disciplines by paying more attention to the peculiarities of the international business environment of South-East Asia, Japan, Singapore and a number of Western culture countries, for example, Australia. 


\section{Foreign investment}

Crisis management in the financial sector

Business planning in the financial sector

Investment management

Problems of applying IFRS in the practice

Financial risk management

Development of financial markets

Financial management

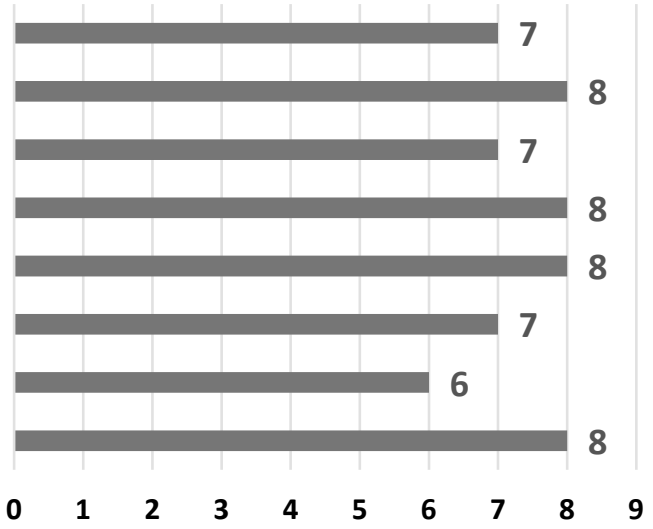

Fig. 3. Assessment of content satisfaction with the content of the mandatory disciplines of master's program of Finance management ( curriculum of 2017)

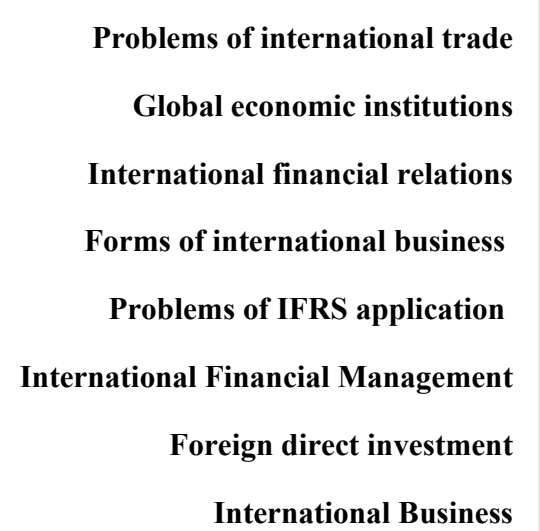

0

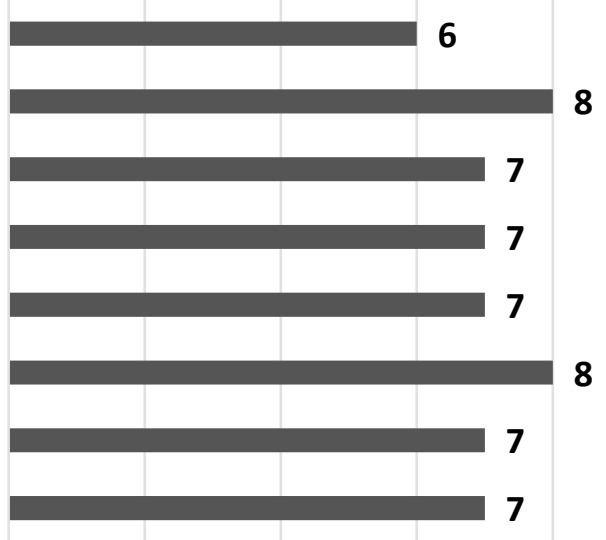

6
8

8

Fig. 4. Assessment of content satisfaction with the content of mandatory disciplines of master's program of International Business (curriculum of 2017)

\section{Disciplines of choice of Matser's program of International Business \\ Disciplines of choice of Matser's program of Finance Management}

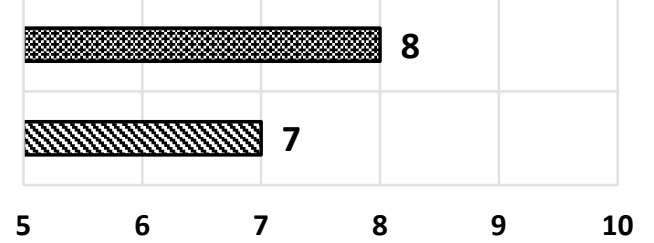

Fig. 5. Assessment of content satisfaction with the content of disciplines of choce (curriculum of 2017) 
The third part of Block 2 is the disciplines of choice. In the two-year curricula adopted in 2017, graduates have assessed satisfaction with the content of 14 disciplines, from which the student could choose to study only seven disciplines within 2 years. According to the authors of both master's programs, the disciplines of choice should be oriented towards the research activities of master's graduates in the future, so the disciplines of choice covered a significant amount of diverse information. However, the survey showed that Chinese students were focused on organizational and managerial activities and to develop trade and economic activities between companies of the Russian Federation and China. Fig. 5 shows satisfaction with the content of the disciplines of choice for both programs (Financial Management and International Business).

\section{Conclusion}

The study shows in general a rather high level of satisfaction of Chinese graduates with the content of both master's programs in the field of management in MPSU. In order to increase the level of competitiveness of Russian higher education, it is advisable to take more fully into account the educational needs of foreign students by identifying them immediately after enrolment of students in master's programs. In the case under consideration, this would allow us to adjust the set of disciplines in the direction to strengthen the practical orientation of programs and focus on the individual needs of certain groups of international students, taking into account their future careers and socio-cultural practices in the country in which university graduates are going to work in the position of manager.

\section{References}

1. E. Platonova, J. Bogomolova, M. Musarskiy, O. Igumnov, Procedia - Social and Behavioral Sciences, 214, 393-398 (2015)

2. E. Platonova, O. Fedotova, J. Bogomolova, ICERI2017 Proceedings, 6861-6866 (2017)

3. E. Platonova, O. Fedotova, M. Musarskiy, E. Ulitina, O. Igumnov, J. Bogomolova, ICERI2016 Proceedings, 177-183 (2016)

4. E. Platonova, O. Fedotova, V. Latun, M. Musarskiy, O. Igumnov, EDULEARN18 Proceedings, 10105-10111 (2018)

5. J.V. Freeman, S.J. Walters, M.J. Campbell, How to display data BMJ books, 2008

6. S. Kessler, Zeitschrift für Volkskunde, 114 (2), 282-284 (2018)

7. V. Crisp, M Johnson, F. Constsntinou, Research in education, 105 (1), 18-41(2019)

8. Y. Li, M. Yang, Z.Zang, IEEE transactions on knowledge and data engineering, 31 (10), 1863-1883 (2019)

9. J. Ye, X. Zhu, L. Lo, N.K. Leslie, Teacher and teaching, 6, 53-57 (2019) 